\title{
Residential Construction Sustainability in the UK and Prospects of Knowledge Transfer to Kazakhstan
}

\author{
Serik Tokbolat ${ }^{1} \&$ Rajnish Kaur Calay ${ }^{1}$ \\ ${ }^{1}$ Faculty of Engineering, Narvik University College, Norway \\ Correspondence: Serik Tokbolat, Faculty of Engineering, Narvik University College, Norway. E-mail: \\ stokbulatov@gmail.com
}

Received: May 26, 2015 Accepted: June 16, 2015 Online Published: October 22, 2015

doi:10.5539/jsd.v8n9p14 URL: http://dx.doi.org/10.5539/jsd.v8n9p14

\begin{abstract}
This paper aimed to investigate the up-to-date levels of sustainability in the UK construction with special interest to sustainable housing. It also aims to examine the justification behind construction and housing sustainability, and to look at the practicality of transferring current expertise within the UK as well as to an emerging Central Asian country such as Kazakhstan. A synergy of case studies, survey and numerical simulation research methodologies were applied to undertake a wide-spectrum analysis of the topic. Regardless of difficulties related to applying sustainable practices the considered housing developments are found to be satisfactory in terms of environmental and socio-economic effects. Technical evaluation of the case studies compared to standard housing parameters has shown encouraging outcomes and confirmed the claimed energy and water efficiency. Findings of the survey indicated that construction companies of the UK and Kazakhstan are at different stages of application of sustainability measures. It was also established that companies and public are mainly optimistic about sustainability if suitable economical and legal conditions are ensured. Finally, numerical simulations have shown that selected sustainability measures made the studied housing projects competitive on the sustainability market.
\end{abstract}

Keywords: sustainable development, sustainable construction, housing sustainability, energy efficiency, case studies

\section{Introduction}

Sustainable construction is a construction activity which incorporates the essential concepts of sustainable development. It targets to design, construct and manage a healthy built environment on the pillars of the effective and environmentally cautious usage of natural wealth. Moreover, it aims to reducing the ecological consequences throughout the whole life cycle of a structure, and at the same time sustaining its economic feasibility and guaranteeing the wellbeing and comfortable conditions for its inhabitants [1]. The philosophy and application of sustainable construction are not at the same level in Kazakhstan as in the UK. This is largely due to different objectives and levels of importance of sustainability.

This paper is party based on and is expansion of the previous research carried out within the Master degree study accomplished by the main author at the University of Nottingham, UK.

\subsection{Sustainable Construction in the UK}

Sustainable construction is a crucial concern at present for the UK administration as well as a range of groups related to the construction sector. With the purpose of helping to address climate change impacts, the UK has established ambitious objectives for the decreasing of $\mathrm{CO}_{2}$ emissions by nearly $80 \%$ by 2050 , with real accomplishments by 2020 [2]. This strategy needs substantial $\mathrm{CO}_{2}$ reductions from all sectors, especially the housing construction segment. At present the housing construction is in charge for almost $30 \%$ of the UK's entire carbon discharges [2]. The UK administration has constantly stressed the importance of the construction sector, predominantly the house building segment, in terms of the total decrease of $\mathrm{CO}_{2}[3]$.

Different policies have been adopted to foster the progress of sustainability principles incorporation within the industry. In 2008, the UK administration introduced a document called Strategy for Sustainable Construction. Prior to that in 2007, a policy for the construction of new housing called 'Homes for the future: more affordable, more sustainable' was released. The policy revealed the increasing housing shortage in the UK and also stressed that new 
housing is required to be low energy to help decrease the level of $\mathrm{CO}_{2}$ emissions [2]. With the intention of advancing housing standards, the government has also established a Code for Sustainable Homes - a state standard for the new sustainable housing [4]. In addition, construction requirements have become stricter to reach another challenging target of constructing only 'zero-carbon' houses starting from 2016 by advancing housing regulations [4]. Moreover, a number of housing developers have demonstrated several sustainable housing projects, to show that such houses are practical and have a prospect in the UK. Kazakhstan is developing rapidly in terms of house building and infrastructure projects. However, Kazakhstan is far behind the UK regarding legislation, policies and also available expertise in sustainable construction. Therefore, there is less specific information available on legislation and strategies with respect to sustainability. But it is vital to study the UK's sustainability agenda and explore the possibilities of knowledge and experience transfer to Kazakhstan perspective. This paper presents an investigation of UK policy framework relevant to sustainable development and its transfer potential in the context of construction industry in Kazakhstan

\subsection{Sustainable Construction in Kazakhstan}

Kazakhstan is a rapidly developing Central Asian country with a large territory (the size of five Frances) and a rich fund of mineral and fossil fuel resources [5]. Kazakhstan's economic development during last two decades has led to a boom in the construction sector. PMR Publications [6] report that the rate of construction output increase in Kazakhstan has reached almost $800 \%$ during the last ten years. A substantial part of construction activities are found in the housing construction as a result of a wide number of state programs which aimed to raise the supply of housing and, thus, reducing housing shortage. Kazakhstan's administration recognizes poor levels of sustainability in construction industry and is attempting to tackle these problems. However, most of the actions tend to be related to consequences but not sources of problems. There is a significant need for advanced awareness, expertise in terms of sustainability, and for the administration's commitment to sustainable future.

This confirms the significance of studying the knowledge and practice that already exists in other developed countries such as the UK and searching ways of using them in developing countries like Kazakhstan. For that reason, a literature survey, case studies and questionnaire surveys were performed among construction organizations and the public to gather information on the present state and future potentials of sustainable housing and construction in general in both countries, It is envisaged that the findings of this study will help to identify problematical areas and to find potential ways for further improvements.

\section{Methodology}

This study applied an integrated approach using a combination of case study, survey and numerical simulation research methodologies. A detailed analysis of two sustainable housing projects was undertaken and conclusions made about their main construction and operation approaches. The case study technique is the qualitative examination of a specific element/unit which endeavors to recognize the key features and parameters that caused its success or failure [7]. The case studies are built on existing reports and available data gained from project developers and other ecological organizations that were involved in the realization of the projects. Moreover, different private and open studies concerning the pros and cons of the developments were considered to critically analyze the social and environmental effects of these housing projects. A comparative analysis of these projects with conventional housing is also presented for showing the justification for their implementation.

The quantitative examination has been carried by means of stakeholders' survey. Survey is a research technique that adopts quantitative examination and via which data from a range of individuals and groups are collected through questionnaires, consultations or assessment of available statistical data [8]. The results of a survey are normally applied to distinguish the attitudes, views and opinions of the general public or a certain demographic group [9]. This survey made possible finding out existing data with respect to companies' and the general public's level of understanding of sustainability and their up-to-date approaches and opinions. Outcomes of the survey allowed determining motivators and hinders of construction sustainability. Additionally, the survey results were useful for a comparative assessment between the UK and Kazakhstan and allowed the documentation of challenging as well as positive aspects of the countries' construction sectors, thus, allowing delivering conclusions on viability of expertise transfer within the UK and to Kazakhstan.

In order to assess energy performance of selected buildings and their comparison with standards, a computer or numerical simulation tool was used. This tool allows quick building modeling with dynamic energy simulation.. Computer simulations are widely used researchers, engineers and practitioners in order describe the behavior of a system and perform parametric analysis at a relatively low cost. In this study, the Design Builder software was used which allowed producing a wide range of environmental performance data for buildings. Sub-hourly simulation time periods with application of EnergyPlus simulation tool was then used to simulate energy 
consumption for sub-hourly time periods.

\section{Results and Analysis}

\subsection{Case Studies and Comparative Analysis}

Two projects; BedZED and Hockerton Housing Project were chosen for comparative study (Fig 1 and Fig. 2). The BedZED project is as an exceptional case of an environmentally-prudent and publicly attractive housing development constructed in urban settings [11].

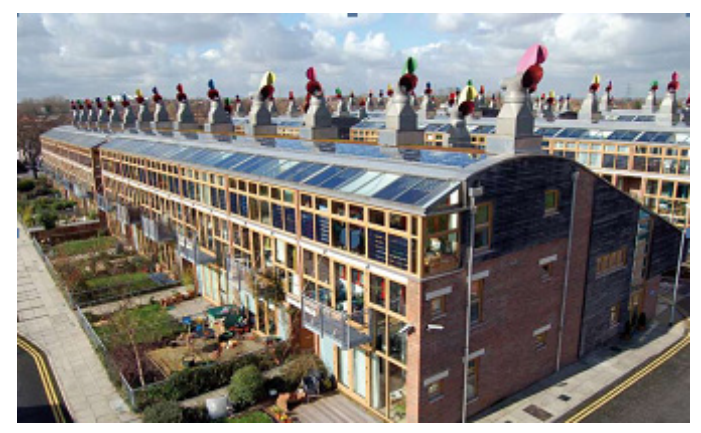

Figure 1. Bed ZED [11]

Whereas the Hockerton Housing Project (HHP) is a state-of-the-art example of a rural, environmentally autonomous and low energy housing project [12].

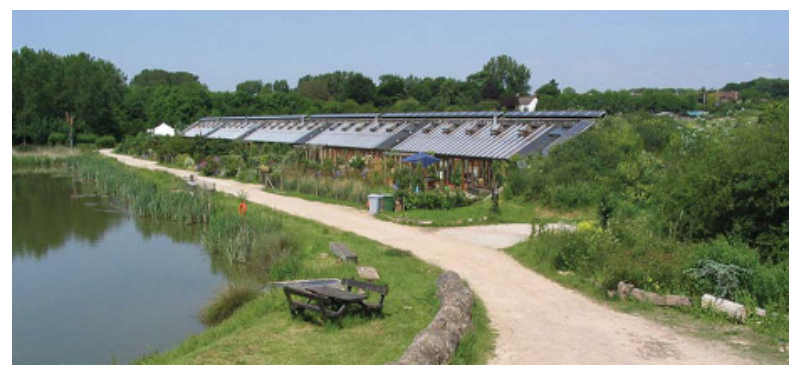

Figure 2. Hockerton housing project [12]

Information on the energy consumption, water usage, sewage system and overall $\mathrm{CO}_{2}$ emissions were estimated for both projects. The comparison of main parameters for these projects was carried out with conventional dwelling on the basis of construction requirements for new as well as existing buildings. The required data were obtained from several construction standards and data sources on mean energy and water use in the UK.

\subsubsection{Carbon Emissions}

According to SAP [13], a typical house that consumes gas or coal for space heating and electricity production must have a carbon dioxide quantity of no greater than $0.194 \mathrm{~kg} / \mathrm{kWh}$ and $0.291 \mathrm{~kg} / \mathrm{kWh}$ respectively. For the BedZED and the HHP these numbers are equivalent to $0.025 \mathrm{~kg} / \mathrm{kWh}$ and nearly $0 \mathrm{~kg} / \mathrm{kWh}$ correspondingly. Most likely the BedZED has reached this number as a result of use of Combined Heat and Power (CHP) equipment that works on carbon neutral wooden chips. The HHP designers, in turn, informed that the $\mathrm{CO}_{2}$ value is nearly $0 \mathrm{~kg} / \mathrm{kWh}$. It is not unexpected as the houses primarily rely on solar energy for heating and sustain thermal mass, therefore, excluding the necessity for heating system. As for electricity production, the development mainly depends on non-fossil fuel sources of energy harnessing it by photovoltaic elements and wind vents.

\subsubsection{Water Use and Sewage Management}

According to DEFRA [14], the mean water use value in the UK is close to 150 liters per person/day. Average amount of consumed water for the BedZED and the HHP has been compared with this value. For example, while the five year average water use in the BedZED was reported to be nearly 90 liters mainly as a result of combination of rainwater collection tanks and using water efficient equipment [15]. Meanwhile, the HHP's average was stated to be 0 liters. This value was achieved by means of its autonomous rainwater collection arrangement. The dwelling entirely depends on rainwater, and therefore does not get water from the district system [16]. The dwellings are 
also sustainable due to minimized release of waste water into the district sewage network. Both developments introduced their private sewage management arrangements including composting and reed-bed treatment $[15,16]$.

\subsubsection{Energy Consumption}

According to DEFRA [14], the mean energy use value in the UK is growing by $1.5 \%$ per annum and must be cut by $2.4 \%$ per annum for the country's target of an $80 \% \mathrm{CO}_{2}$ cut by 2050 to be successful. To reach these targets, both energy generation and its use practices have to be reconsidered. The housing segment that is responsible for a notable part of energy consumption reaching around $40 \%$ has to adopt new approaches and low energy appliances to address existing and potential problems (BERR, 2010). According to BERR [17], today's average electricity use is $5.50 \mathrm{kWh}$ per person/day. In turn, the BedZED's average is $3.40 \mathrm{kWh}$ per person/day, $38 \%$ lower than the UK's mean value. The HHP's mean, in turn, is only $0.55 \mathrm{kWh}$ per person/day, $90 \%$ less than the UK average [16]. Both projects have reached this level of energy use cuts by means of passive solar energy technologies and low energy equipment. Furthermore, energy requirements are partially supplied by on-site renewable energy production.

Table 1. Total water use [16]

\begin{tabular}{ccc}
\hline $\begin{array}{c}\text { BedZED 2003 } \\
\text { litres/person/day }\end{array}$ & $\begin{array}{c}\text { BedZED 2007 } \\
\text { litres/person/day }\end{array}$ & $\begin{array}{c}\text { Local average for metered properties } \\
\text { litres/person/day }\end{array}$ \\
\hline 91 & 87 & 143 \\
\hline
\end{tabular}

Table 2. Total energy use [16]

\begin{tabular}{cccc}
\hline & & BedZED 2007 & UK Average (based on dwellings built in 2002) \\
\hline \multirow{2}{*}{ Heating \& hot water } & $\mathrm{kWh} / \mathrm{m}^{2} / \mathrm{yr}$ & 48.0 & 231.8 \\
& $\mathrm{CO}_{2} / \mathrm{m}^{2} / \mathrm{yr}$ & 9.3 & 45 \\
\multirow{3}{*}{ Electrical load } & $\mathrm{kWh} / \mathrm{m}^{2} / \mathrm{yr}$ & 34.4 & 45.5 \\
& $\mathrm{CO}_{2} / \mathrm{m}^{2} / \mathrm{yr}$ & 10.6 & 18.4 \\
\multirow{2}{*}{ Total energy use } & $\mathrm{kWh} / \mathrm{m}^{2} / \mathrm{yr}$ & 82.4 & 275.3 \\
& $\mathrm{CO}_{2} / \mathrm{m}^{2} / \mathrm{yr}$ & 19.9 & 63.3 \\
\hline
\end{tabular}

\subsection{Survey Results. Construction Companies}

1) Current awareness and application of sustainability measures. Even though here is a broad awareness with regard to three key aspects of sustainable development, it was established that organizations define sustainability differently. For example, as shown in Figure 3, if around 33\% of UK companies' representatives linked sustainability with ecological issues, almost $28 \%$ of Kazakh respondents perceived it to be a financial characteristic of construction process. The survey has also determined that the significant number of big companies in the UK have implemented sustainability strategies. This shows a greater level of sustainability principles within the UK industry compared to Kazakh construction. Even though nearly $50 \%$ of respondents from Kazakhstan stated that they have existing sustainability policies, it should be borne in mind that these policies are different from the ones in the UK.

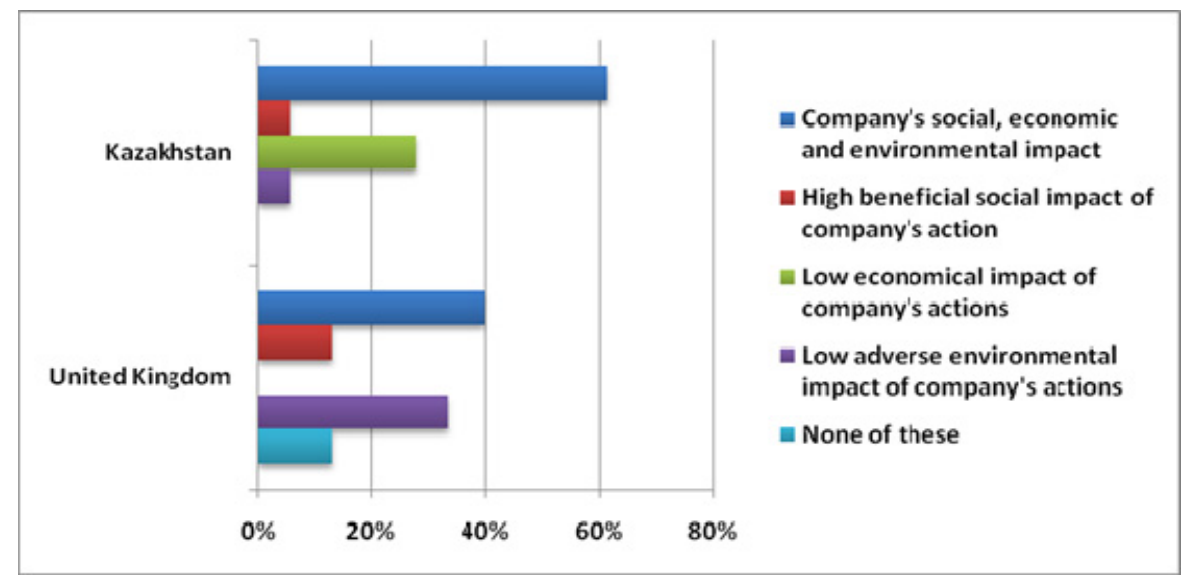

Figure 3. Sustainability awareness 
2) Drivers and barriers of sustainable construction. Respondents were asked to level the essential drivers and barriers to application of sustainability measures. The top ranked drivers for UK are found to be government enforcement, reputation issues, the client's procurement scheme, the anticipations of clients and market. Osmani and O'Reilly [18] and Adetunji et al. [19] found that construction entities in the UK think that the government has to reconsider present sustainability requirements and incorporate clearer and more accurate regulations to be successful in its aim to contribute to formation of construction sustainability.

Kazakh respondents' ranking is as follows: the anticipations of clients, government enforcement, environmental concerns, reputation issues and the anticipations of shareholders and future occupants. Respondents indicated government and legal enforcement as the crucial driver in encouraging sustainability. This subject is very important in Kazakhstan as there is no reliable strategy that stimulates sustainability at industry scale. Existing sustainability strategies are seen to have preventive nature rather than proactive [20]. Market needs are perceived by respondents as a crucial prerequisite of sustainable construction, which was also mentioned by Carter [21] and Darnton [22].

The survey has determined key impediments of realizing sustainable construction. For organizations in Kazakhstan, these barriers are economic restrictions, strict regulations, poor awareness of sustainability and a short period focus. For companies in the UK, economic restrictions, a short term focus and strict regulations are perceived as the key restrictions. According to WWF [23] and Williams [24], economic expenses to implement sustainability were determined as being very costly.

3) Prospective of construction sustainability. When asked on the perspectives of sustainable construction and their readiness to participate, the respondents showed optimistic views. Though the greater number of companies from both states believed sustainable measures as hypothetically cost-effective, doubters continued to stress on problems of financial feasibility of such measures.

In spite of the higher initial expenditures of introducing sustainable practices, around $50 \%$ of the respondents showed a readiness to join to construction of sustainable developments. At the same time, nearly $30 \%$ stated that such participation will be subject to the optimal expenditures and the readiness of customers to share duties. Finally, some companies in the UK and Kazakhstan stated that they would rather continue applying conventional practices.

\subsection{General Public.}

1) Awareness and support of principles of sustainable construction. As expected, the state of awareness of sustainability is found to be not the same in the UK and Kazakhstan. Almost $50 \%$ of Kazakh respondents thought that their understanding was either 'very poor' $(15 \%)$ or 'low' $(36 . \%)$, whereas in the UK general public awareness of sustainability is higher. Only $9 \%$ and $31 \%$ thought their understanding very poor or low respectively). The percentage of 'moderate' and 'good or excellent' replies was also greater for UK respondents; $45.00 \%$ and $12.00 \%$ in contrast to $32.00 \%$ and $10.00 \%$ in Kazakhstan. The greater understanding level in the UK could be due to broader penetration of the sustainability concept in the UK culture. General support by the public gained $100 \%$ for the UK respondents and $78 \%$ for Kazakh ones. More optimistic viewpoints of the UK respondents are most likely related to high importance of the concept at the state level.

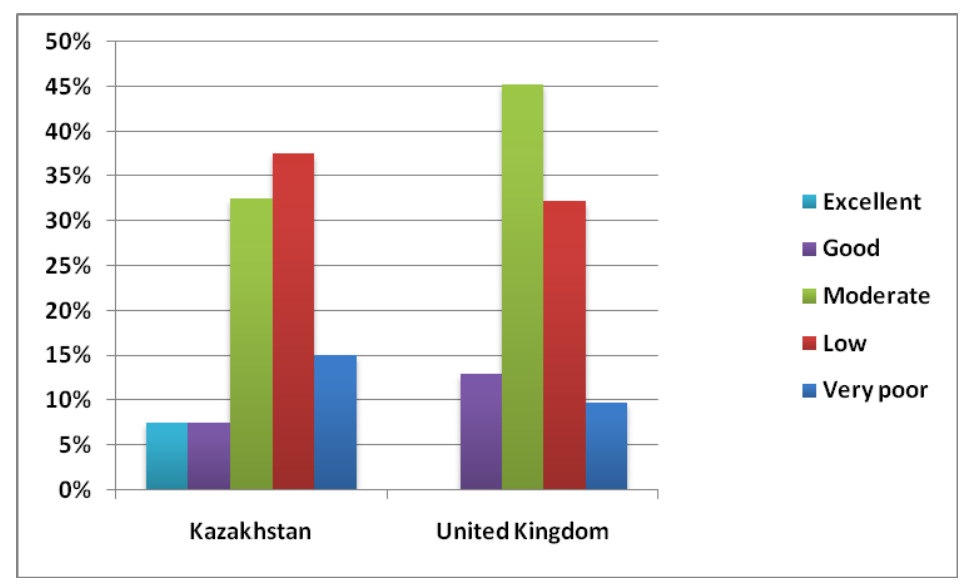

Figure 4. Sustainability awareness breakdown 
2) Current state of sustainable housing construction and its barriers. The survey outcomes confirmed anticipations of the study with regard to different levels of housing sustainability in the UK and Kazakhstan. For example, all Kazakh respondents thought that sustainability has not been adequately dealt with, whereas in the UK the state of affairs is different. If nearly $50 \%$ of respondents shared pessimistic views, almost $35 \%$ believed that sustainable construction is effectively managed. The question about barriers that hinder the integration of green housing construction exposed that Kazakh respondents view 'a lack of experience and practice' as being a significant barrier on construction companies (3.59), 'poor legal enforcement (3.54), 'poor understanding of the concept' (3.44) and 'economic burdens' (3.33). In the UK, economic limitations were perceived as the greatest barriers to sustainable construction (3.42), poor enforcement and understanding (both 2.87), and 'low demand for sustainable housing' (2.81).

3) Pros and cons of sustainable housing. Unexpectedly, the level of importance of existing pros is almost equal for respondents from both countries. According to the Likert scale (from 1 to 4 ) the most significant advantages for Kazakh and UK respondents were 'energy and water efficiency' (3.67 and 3.58), 'healthy indoor climate' (3.69 and 3.26), 'safety from future rise of energy and water costs and environmental strategies' (3.44 and 3.30) and 'low negative impact during an entire life cycle' (3.23 and 3.19). The explanations of higher rankings of aspects energy and water efficiency aspects and future rises in price could be related to economic frustrations of the people of both countries. As for cons, the greatest disadvantage for respondents from both countries is the 'high initial expenditures' for a house. For Kazakh respondents the negative aspect is design related to the specific climate of the country with extreme seasons. In the UK, 'higher cost' issues are related to the fairly short span of housing ownership and difficulties of reselling and payback on the investment.

4) Prospective of sustainable housing. As anticipated, the importance of sustainable housing in five years' time span was found to be country-dependent; UK public is more positive compared Kazakh's. Nonetheless, in spite of the expensive nature of sustainable practices and additional drawbacks related to sustainable housing, the main part of respondents showed enthusiasm to buying a "green" house. On the other hand, for several respondents such a decision will be subject to economic viability, the locality and quality of the house, while remaining respondents needed to think about the average time of stay as well as payback time of the extra expenses related to sustainable measures.

\subsection{Numerical Simulations}

The results of the simulations are based on detailed sub-hourly simulation time periods produced by Energy Plus simulation engine. Energy Plus is a computer simulation engine for energy analysis and thermal simulations. It is developed by the U.S. Department of Energy as a tool to minimize the energy consumption of buildings. The program allows the user to describe a building at a high level of detail. The building's construction, heating system, ventilation system, usage patterns and many other details can be designed and tested. The program also allows calculating the amount of energy required to maintain the set values, the air temperature in different zones of a building and other values depending on the interest of the user. The program has a very high level of detail, and the user can extract values of the individual components in the design or system in the building [25]. The Design Builder integrates the Energy Plus calculation model and the EPBD European standards. In order to build a simulation model the input data such as technical parameters of the building as well as local climate conditions need to be defined. The former has been based on architectural drawings and data relevant to various technical specifications of the buildings obtained from reports of the main construction company that built the considered buildings. The latter is based on metrological data obtained from the Internet. All the relevant details are presented below.

\section{1) Building description}

The overall floor area of the BedZED housing development is $10388 \mathrm{~m}^{2}$. These include residential, commercial, office and leisure spaces. Due to the significant share of residential spaces it was decided to run energy use simulation for a typical residential unit. The selected unit is a single-family commune type dwelling consisting of three bedrooms, a living room/kitchen, a room for leisure, two bathrooms, a sunspace and sky gardens. The example layout and section view of the house are presented in Figure 5. The living spaces are oriented towards south and the house is located on a flat area. Materials for construction are selected carefully to create an efficient thermal mass. The structure consists of concrete block work and concrete floor slabs. As shown in Figure 6, the envelope is covered by $300 \mathrm{~mm}$ insulation jacket. The dwelling includes triple-storey conservatories to ensure maximum passive solar gain. Finally, passive ventilation with heat recovery system is installed to recover heat from occupants and equipment. 


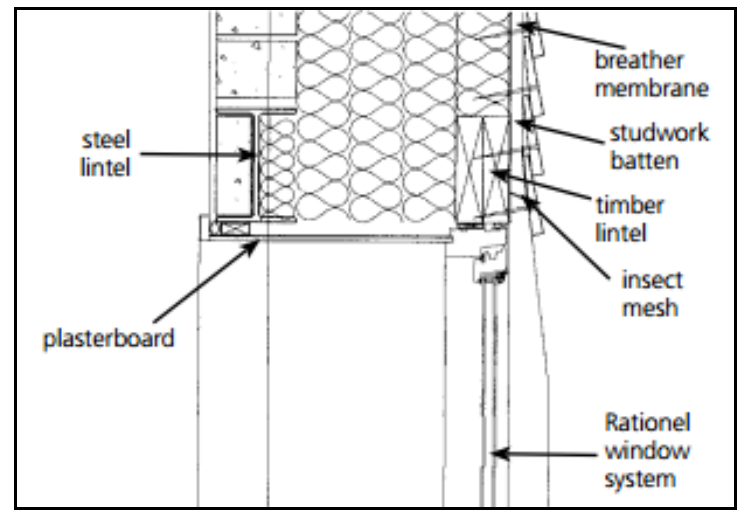

Figure 5. Section view of the wall [11]

\section{2) Climate data}

The calculation of energy use of a building is influenced by a range of aspects including local climate parameters. According to the climate classification map, London - location of the BedZED project, is categorized by a temperate climate with four distinct seasons. The coordinates of London are $51^{\circ} 51^{\prime} \mathrm{N}, 2^{\circ} 00^{\prime} \mathrm{W}$ [26]. Specific climate data including average monthly temperature and predominant wind direction for London has been obtained and used as input data for simulation purposes. The temperature distribution during a typical metrological year is presented in Figure 6.

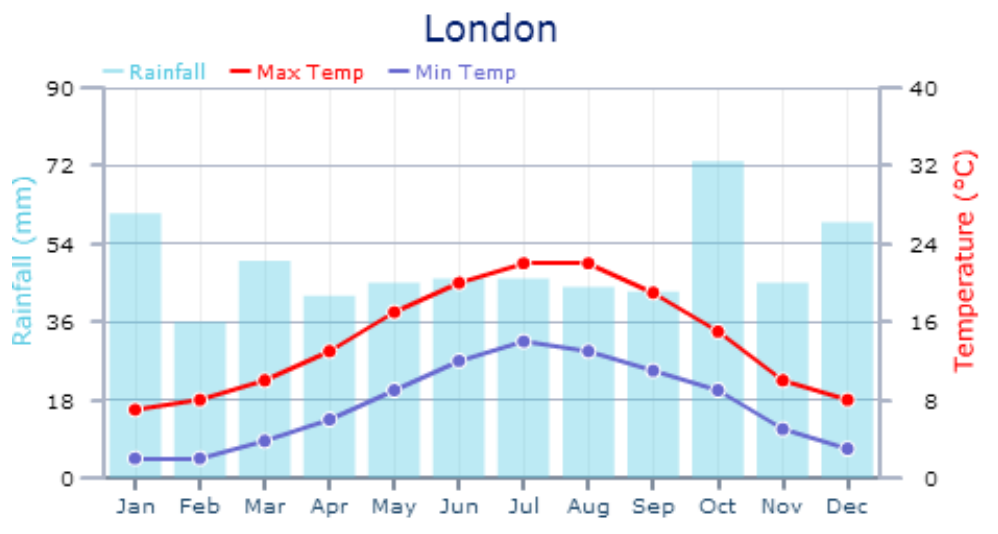

Figure 6. Max/min temperatures and rainfall vs. months [26]

Predominant wind direction in London is South-West. The yearly average wind speed is 9 kts [26]. Relative humidity average is $92.3 \%$ with relatively small fluctuations throughout the year [27]

\section{3) Building model}

The 3D architectural drawings have been developed in Design Builder

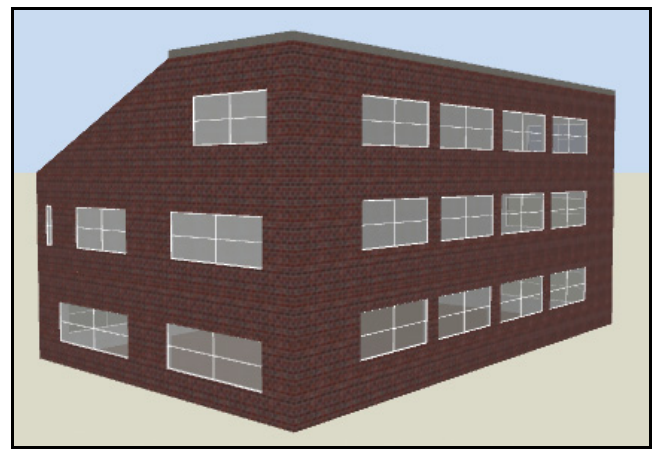

Figure 7. Bed ZED simulation model 
The results have shown that the simulation model house uses $89,17 \mathrm{kWh} / \mathrm{m}^{2} /$ year. This is almost equal to the report value of the BedZED project shown in Table 2 corresponding to $82,4 \mathrm{kWh} / \mathrm{m}^{2} /$ year. The relatively small difference of the results is most likely due to a number of assumptions made during constructing and simulating the model. Among these assumptions are several unknown design parameters, for example, actual infiltration rate or the efficiency percentage of building control systems. Nevertheless, assumptions of these and other non- specified by the contractor-company parameters have been made according to the best practice guidelines available for low energy buildings. The comparison of the simulation result and the actual energy use rate leads to the conclusion that the simulation model is validated. Thus, the model could be adjusted for different climate settings. As the purpose of this study is to investigate prospects of knowledge and experience transfer to Kazakhstan, the model was simulated for Kazakhstan's weather conditions. The climate data of Kazakhstan (Astana) has been obtained from [28]. According to this code, the average yearly temperature distribution is shown in Figure 8.

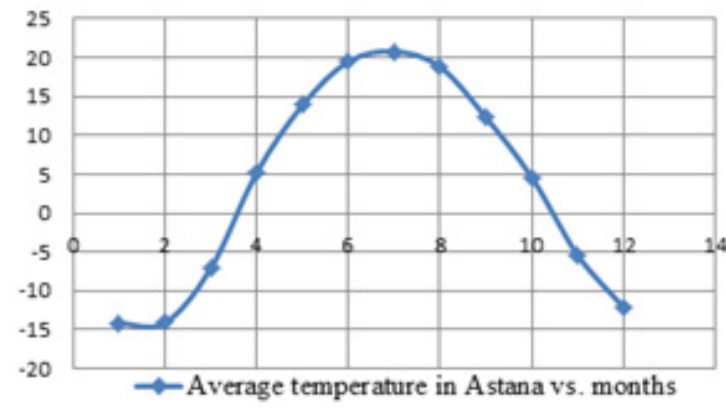

Figure 8. Average monthly temperature in Astana [28]

The simulation of the model in Kazakhstan's conditions has found that the total energy use by the building is $274.01 \mathrm{kWh} / \mathrm{m}^{2} /$ year. This value is significantly higher than the energy use value for London's conditions. This result confirms the anticipation of higher energy use due to significantly lower average temperature in Astana. These are few parameters that tend to cause higher energy use by the model. In order to get same energy consumption in Kazakhstan's conditions, the design needs to be significantly modified. Construction materials (with U-values) used in the model are not applicable for Kazakhstan climate which is much colder than the UK average climate. Similarly, wall-to-window ratio should be significantly lowered for Kazakhstan's case. Low temperatures and strong seasonal winds most likely cause considerable heat loss through windows. Furthermore, heating as well as other control systems should be reconsidered according to new requirements. To conclude, future research should consider different technical specifications for construction materials, U-values of envelope components, windows-to-wall ratio and HVAC system applicable for Kazakhstan's conditions. This conclusion emphasizes the importance of carefully learning the methods of the low energy building design and construction in the UK and modification of the techniques for Kazakhstan climate conditions. Because the transfer of knowledge and experience in this field is not possible as a result of mere copying the model. Different climate conditions require complete reconsideration of wide number of design parameters.

\section{Conclusions}

The quantitative study has showed that the considered housing projects are, in fact, superior in terms of sustainability measures compared to conventional dwellings. Particularly, this was proved with regard to energy and water consumption, $\mathrm{CO}_{2}$ emissions and several social and financial parameters. In spite of the difficulties related to introduction of the state-of-the-art design solutions and advanced "green" know-hows considered in the review of the projects, the houses are perceived as means of helping to achieve the government's goals of $\mathrm{CO}_{2}$ cuts along with efficiency of energy and water usage. The paper has confirmed initial assumptions that while sustainable measures are mostly understood and welcomed in the UK and in Kazakhstan; proactive actions from the governments and construction companies are vital. The paper has found a number of aspects that require serious care from both governments, among which are to put emphasis on the importance of sustainable construction, particularly in the housing segment, and to introduce effective regulations. There is also a demand for a reconsideration of values of sustainability to help the construction sector in acceptance of sustainable measures and to increase understanding and response of customers. Furthermore, economic motivations by the government must be applied to appeal to construction companies and clients to engage with sustainable housing.

The numerical simulation results were in agreement with the findings of the BedZED case study. The development 
in fact, consumes significantly less energy compared to a conventional residential building in the UK. However, when the model was tested for Kazakhstan's weather conditions it became apparent that the design parameters need to be significantly modified to the local climate. This also confirms the need for Kazakhstan to develop her own specifications for construction materials U-values of envelope components, windows-to-wall ratio HVAC and construction practices according to the Kazakhstan's climate conditions in order to achieve energy and $\mathrm{CO}_{2}$ targets similar to $\mathrm{CO}_{2}$ neutral buildings.

\section{Notes}

Note 1. Arch, 2009, Sustainable architecture and building design. Adopted from http://www.arch.hk/[Accessed date: 11 March 2014]

Note 2. DECC, 2008, UK leads world with commitment to cut emissions by $80 \%$ by 2050 . Department of Energy and Climate Change. Adopted from http://www.decc.gov.uk/ [Accessed date: 12 March 2014]

Note 3. DTI, 2003, Ebergy white paper: our energy future - creating a low carbon economy. Department of Trade and Industry, Norwich

Note 4. DCLG, 2001, Code for Sustainable Homes. Adopted from http://www.communities.gov.uk/ [Accessed date: 12 March 2014]

Note 5. BBC, 2010, Kazakhstan country profile. Adopted from http://news.bbc.co.uk/ [Accessed date: 13 March 2014]

Note 6. Pmrpubcications, 2007, Value and real growth rate of construction output in Kazakhstan. Adopted from http://www.pmrpublications.com/[Accessed date: 15 March 2014]

Note 7. Cleary, 2007, A report on energy efficient design principles applied to Beddington zero (fossil) energy development at Beddington. Adopted from http://www.seanliamcleary.com/[Accessed date: 15 March 2014]

Note 8. CABE, 2007, BedZED. Case studies. Adopted from http://www.cabe.org.uk/[Accessed date: 16 March 2014]

Note 9. ESRU, 2010, Hockerton Housing Project. Adopted from http://www.esru.strath.ac.uk/[Accessed date: 20 March 2014]

Note 10 DesignBuilder, 2014, http://www.designbuilder.co.uk/[Accessed date: 23 March 2014]

Note 11. Greenline, 2010, BedZED - Beddington Zero Energy Development. Adopted from http://greenlineblog.com/[Accessed date: 23 March 2014]

Note 12. White, 2010, Hockerton Housing Project. Adopted from http://www.hockertonhousingproject.org.uk/[Accessed date: 29 March 2014]

Note 13. SAP, 2005, The Government's Standard Assessment Procedure for Energy Rating of Dwellings. Adopted from http://projects.bre.co.uk/[Accessed date: 28 March 2014]

Note 14. Defra, 2008, Climate change. Adopted from http://www.defra.gov.uk/[Accessed date: 30 March 2014]

Note 15. BioRegional, 2009, BedZED seven years on, Report. Adopted from http://www.bioregional.com/ [Accessed date: 03 April 2014]

Note 16. White, 2010, Hockerton Housing Project. Adopted from http://www.hockertonhousingproject.org.uk/[Accessed date: 05 April 2014]

Note 17. BERR, 2010, Regional and local electricity consumption statistics. Adopted from http://www.berr.gov.uk/ [Accessed date: 06 April 2014]

Note 18. Osmani, M., O’Reilly, A, 2009, Feasibility of zero carbon homes in England by 2016: A house builder's perspective.

Adopted from http://www.sciencedirect.com/[Accessed date: 09 April 2014]

Note 19. Adetunji, I., Price, A., Fleming, P., Kemp, P, 2003, Sustainability and the UK construction industry $\neg$ - a review. Proceedings of the Institution of Civil Engineers, No. 156, pp. 185-199

Note 20. UNEP, 2005, The main conditions for the implementation of the environmental policy. Adopted from http://enrin.grida.no/ [Accessed date: 10 April 2014]

Note 21. Carter, E 2006, Making money from sustainable homes: a developers guide. CIOB Publications, Ascot, UK 
Note 22. Darnton, A 2005, Public understanding of climate change. Futerra\&DEFRA

Note 23. WWF, 2004, Building towards sustainability: performance and progress among the UK's leading house builders. World Wide Fund, Surrey, UK

Note 24. Williams, K., Adair, C, 2007, What is stopping sustainable building in England? Sustainable Development, No.15, pp.135-147

Note 25. Joisten, W, 2012, Energy supply solutions for Norwegian low energy commercial buildings, NTNU master's thesis.

Note 26. Metoffice, 2014, Climate in London. Adopted from http://www.metoffice.gov.uk/public/weather/Accessed date: 23. April 2014]

Note 27. Widnfinder, 2014, Windstatistics. Adopted from, http://www.windfinder.com/windstatistics/east_london [Accessed date 23 April 2014]

Note 28. Construction Climatology "Construction Norms and Regulations of Kazakhstan (CNRK) 2.04-01-2010" (СНиПРК 2.04-01-2010), Almaty, 2011

\section{Copyrights}

Copyright for this article is retained by the author(s), with first publication rights granted to the journal.

This is an open-access article distributed under the terms and conditions of the Creative Commons Attribution license (http://creativecommons.org/licenses/by/3.0/). 